\title{
Colonial Politics, Missionary Rivalry, and the Beginnings of Seventh-Day Adventist Mission in Northern Nigeria
}

\author{
John Garah Nengel† \\ Professor of History, University of Jos, Jos, Nigeria
}

Chigemezi Nnadozie Wogu

Ph.D. Candidate, Vrije Universiteit, Amsterdam, The Netherlands

Chigemez.nnadozie@gmail.com

\begin{abstract}
When compared to its relative success in the Southern and Western parts of Nigeria, Seventh-Day Adventism (s.D.A.) had some difficulties in establishing its mission in the North from the 1930s onward. This paper argues that there were three reasons why S.D.A. missionaries found the North difficult. First, the s.D.A. joined the Christian missionary scene in Nigeria rather late. Second, due to colonial politics, which did not favor the proselytizing aims of Christian missionaries in the North, Adventist missionaries did not find it easy to immediately establish a mission. Third, the difficult beginnings in northern Nigeria can also be attributed to the relationship between s.D.A. missionaries and other mission bodies, which tended towards rivalry, as a result of the "spheres of influence" established by the colonial government.
\end{abstract}

\section{Keywords}

Seventh-Day Adventists - Christian mission - missionaries - colonial authorities Northern Nigeria - mission rivalry 
The coming of Seventh-Day Adventism to Nigeria was in two phases. The first phase comprised the mission attempts of commissioned laymen and selfsupporting missionaries like James $\mathrm{M}$. Hyatt, a black lay missionary from the United States. Hyatt had been working in Ghana and Sierra Leone and went to Nigeria between 1906 and 1907. Another indigenous layman, Benjamin I. Tikili, contributed to the growth of a group of a few Adventists until Jesse C. Clifford was sent to Aba in 1923 .

The second phase of the Adventist mission started around 1913 with ordained and commissioned missionaries, who built upon the work of the first phase. This phase brought David C. Babcock together with three other West African workers: R.P. Dauphin, Samuel D. Morgue, and James J. Hamilton. Babcock seemed the most qualified to lead the mission. He had served as director of the British Guiana Mission until 1905 and came to Nigeria after serving in Sierra Leone and Ghana (approximately 1905-1913). After the Nigerian mission was officially organized in 1913, the Babcock team arrived in 1914, focusing attention on western Nigeria while based in Ibadan. In 1923, southern Nigeria got its official missionary, Jesse C. Clifford, who got in touch with Tikili in Aba, from where Adventism spread in the South (Wogu 2019:1-8).

Adventism in southern Nigeria proved to be a more successful venture than the in West. The combined growth of both regions catalyzed a decision to officially reorganize the work, and the field became known as the Nigerian Union Mission with four constituent missions: Northeastern Nigerian Mission, Northwestern Nigerian Mission, Southeastern Nigerian Mission, and Southwestern Nigerian Mission (Christian 1931:2; McClements 1930:2; Adventist Yearbook 1932:199-220). There were two reasons for making such a decision, knowing that the Nigerian mission was largely among the Yorubas in the West and the Igbos in the Southeast, and without prospects in the North.

Firstly, William McClements, the leader of the Adventist work in Nigeria, was a visionary. Being aware that growth was strongest in the West (Ising 1928:4), he must have been enthusiastic to establish Adventism in the Muslim regions of the North. Around 1924, McClements baptized a number of converts in Ilorin and surrounding towns, although the area had a good number of Islamic adherents (Lashier 1924:3). In 1930, McClements reported the opposition Adventism had experienced in and around Sosoki village in Ilorin Province (also known today as Yowere, in Kwara State). The opposition was settled after the local Emir gave the Adventists some land on which to build a church (McClements 1930:2). Consequently, McClements must have thought it would be possible to establish a mission in the North. 
Secondly, after Adventists had recorded a handful of successes in the face of opposition, plans were made for the North of Nigeria, starting with Ilorin. Although Ilorin was close to the Mission headquarters in Ibadan, the town was considered closer to the North because of its Muslim inhabitants. Hence, a mission station was established at Awtun in the Ilorin Province, probably as a base to fully enter the North (Ising 1928:4; Read 1930:14). This must have been the reason for making John J. Hyde the superintendent of the Northeast Mission.

Accordingly, in 1930, Hyde arrived in Nigeria with the intention of doing mission work in the North. However, things did not turn out as planned. It was not until 1932 that Hyde was firmly established and able to fully launch out from Jengre into several other northern towns. Why did the establishment of a mission station in the North take so much time? Considering the data from extant sources mentioned below, the Adventist missionaries had difficulties in their attempts to establish a mission in northern Nigeria for three reasons. Firstly, Adventists were latecomers to the Christian missionary scene in Nigeria. Secondly, the colonial politics at that time did not favor the proselytizing aims of missionaries in the North. Finally, due to the "spheres of influence" established by colonial authorities, there was rivalry between the Adventist missionaries and the Sudan Inland Mission (s.I.M.) workers, which slowed the Adventists' pace considerably.

Before expatiating on these points, a caveat on sources and positionality is helpful. To be able to tell the Adventist story in Northern Nigeria, a number of primary sources were consulted. The archival sources used to reconstruct the history were mostly found in the Nigerian national archives of Jos, Kaduna, and Zaria, especially letters and documents related to the establishment of the Seventh-Day Adventist (s.D.A.) mission. While data dealing primarily with Muslim sources was not the focus here, some materials were consulted due to their relevance to the subject. Additionally, archival documents stored abroad were not consulted because of distance and data saturation found in Nigeria.

Furthermore, news items and mission reports of S.D.A. missionaries contained in extant Adventist periodicals added to the archival data found in Nigeria. Additionally, a number of historical works and monographs were consulted as supplements, especially in the article sections where the authors could only rely on published articles or books to augment archival sources.

Lastly, the historiographical efforts of this article were pursued by the authors, who also identify as Adventists, in an attempt to fill a gap in the broader history of Christian missions in Northern Nigeria. That lacuna refers to the history of the establishment of the S.D.A. mission as an unlikely group among other Christian missions. The efforts pursued here ordinarily do not 
appear in scholarship on mission historiography in Nigeria. Thus, the contributions of this paper bear significance to mission historiography, that of Adventists in particular, and Christian mission in general.

The S.D.A. Church was a latecomer to the missionary scene of Nigeria. Historically, there were two attempts to establish Christianity in Nigeria. The first dates back as far as the sixteenth century with Portuguese Catholic missionaries sent to the Kingdom of Benin (Egharevba 1968:26-27). However, the kingdom was in the middle of inter-tribal wars and was only interested in the religion if the missionaries came with a trade bag of firearms. Unable to make an impact, the missionaries soon left (Ajayi 1965:2; Watson 1996:126). Some Catholic influence continued until the early 1800 s, but not without interruption. Regrettably, the new religion remained confined to the royal court (Baur 1994:76; Hastings 1994:119; Ajayi 1965:3).

Christian missionaries in Nigeria were more successful in their second attempt from around 1841 to 1914, when Protestant missionaries came from Britain with the aim of Christianizing the African continent. Of interest here is the exploration of the Niger River (1830-1857), which was "intended to undermine the slave trade ... and to open up the Africa interior to Christianity and commerce" (Isichei 1995:171). It laid the foundation for the Christianization of cities along the Niger and in Igboland through the Niger Expedition. The expeditions had freed slaves and educated Christians as members, including Samuel Ajayi Crowther, who later became the first African Anglican bishop.

With the opening of Yorubaland (West and Southwest), Igboland (South/ Southeast), and the Hausa regions (North) by the C.M.S., other Christian missions followed suit, so that by the turn of the 2oth century several Christian churches had gained a footing in Nigeria. Moreover, as Christianity was spreading rapidly in the South, Islam, through its jihad conquests, was spreading in the Northern region and to the South, invading Oyo and Ilorin until it was defeated in Oshogbo by the Ibadan army.

Furthermore, by early 2oth century, British colonial rule, which had begun in the 19th century, established a firm grasp on present-day Nigeria. The modern Nigerian state originated when the Southern and Northern Protectorates were amalgamated by Lord Frederick Lugard in 1914. It was the same year that the s.D.A. officially entered the West of Nigeria through David Babcock and his African missionary associates after unsuccessful earlier attempts. 
Therefore, by the time Adventists arrived, the Nigerian missionary arena was marked by significant missionary presence in the West and South, and in Islamic strongholds in the North, all governed by colonial governmental policies. As late comers, Adventists had to deal with these elements. In the West and especially the South, Adventism was successful. The North, with different colonial policies and an Islamic presence, was not entered until the 193os; and its colonial policy regarding Christian proselytizing caused some difficulty for Adventists.

Christian Mission and Regional Authorities: Colonial Politics and the Implementation of Indirect Rule

The colonization of Nigeria was a prolonged process. According to Falola and Heaton, it took more than forty years because "circumstances and the influence of missionaries, traders or French and German incursions tended to dictate the process of colonization; in the end however, territories were brought into submission only by the use of force" (Falola and Heaton 2008:109). The use of force helped to unify independent states, regions, and kingdoms. In the case of Nigeria, Falola and Heaton have argued that colonization "brought under the sole rule of the United Kingdom previously independent states that had been interconnected commercially and to some extent culturally over the previous centuries but had not experience political unification of any kind" (2008:109). Hence modern Nigeria was birthed by unifying several kingdoms, chieftaincies, and independent states belonging to the Southern and Northern protectorates.

However, colonial rule in Nigeria did not stop at mere unification. Indirect rule was used by the British to control and supervise colonies through preexisting indigenous power structures. In Nigeria, while indirect rule was not successful in the South, it functioned well in the Northern regions. The colonial administration in Northern Nigeria had significant policies governing the opening of the Christian missions and operations in the region.

When Lugard conquered the Sokoto Caliphate between 1900 and 1905, being quite aware of Islamic sensibilities, he promised the Muslim rulers that he was not going to interfere with their religion. This promise, as Andrews Barnes has established, was made under the false assumption that Islam was by default the religion of the people in the North (Barnes 1995). The implication of this was that the Christian missionaries were permitted to propagate their religion only among non-Muslim societies. There were two reasons for this. 
Firstly, by this time, Christianity was quite successful among non-Muslim societies. Factors such as the introduction of educational programs, the use of medical work, and the influence of Black/African missionaries contributed to the success (Danmole 199o; Faught 2001; Galadima and Turaki 2001). These positive developments caused Muslims to resent Christian missionaries and their converts. According to Marinus C. Iwuchukwu, contrary to Islamic theological teachings, Christians were generally considered as unbelievers Kafir - by the Fulani Muslims North of the Niger (Iwuchukwu 2013:22). This hatred was also transferred to the British colonial authorities, seen as agents of Christian propagation. Therefore, in order to show that their presence in the Hausa and Fulani territories had nothing to do with the Christians, or with being seen as advocates of Christianity, Lugard and his associates had to emphasize their position by promising not to interfere with the Islamic religion. This eventually earned Lugard the loyalty and cooperation of the Northern leaders and the promotion of indirect rule (Iwuchukwu 2013:20, 21).

Secondly, it is possible that Lugard himself had come to dislike educated Christian converts who mostly came from the South. In fact, it seemed he saw them as threats to successful indirect rule. Therefore, he "disdained the European-educated Nigerians [...] claiming that mission schools inculcated in their pupils 'discontent impatience of any control, and an unjustifiable assumption of self-importance in the individual,' all of which made the educated Nigerians a threat to both the British rule and traditional social norms" (Falola and Heaton 2008:129).

Lugard not only disliked the Christian converts, but also had a certain level of distrust toward missionaries because they empowered the converts. Thus, he encouraged every colonial administrator to "cordially welcome the establishment of Missions among pagan tribes - except, perhaps, that type of mission ... whose actions however well intentioned, degrade the European in the eyes of the native" (Lugard 1965:59o, cited in Barnes 1995:427). Put differently, Lugard did not want any Christian ideology of empowerment that would interfere with indirect rule or challenge colonial powers in the Muslim North. In fact, as he made clear in his "Amalgamation Report," the colonial authorities wanted "to ensure that a class of Christian converts did not arise to challenge British authority in the North as they had in the South" (Barnes 1995:428).

Nevertheless, Iwuchukwu, likely through the influence of E.O. Ayandele, argues that Lugard was not completely opposed to Christian missionaries and their activities but just ensured that they did not tarnish the relationship with the Northern leaders nor hurt his administration there (2013:23). This argument holds sway, for despite the restrictions, Lugard made some exceptions to the C.M.S. missionaries, since his mother was a missionary in 
the same organization. Besides, he regarded C.M.s. missionaries as educated men "with sympathies similar to those of colonial officials" (Barnes 1995:424). Additionally, aside from his friendship with Walter Miller, a c.M.s. missionary, during Lugard's leadership permission was given to some Christian mission endeavors in parts of the North: the Toronto Industrial Mission at Pategi (1899); C.M.S. in Bida (1902) and Zaria city (1904); the Cambridge University Mission Party (later Sudan United Mission, s.U.M.) in Wase, Nassarawa province, and the Mennonite Brethren of the USA in Ilorin in 1905 (Iwuchukwu 2013:24).

However, in 1906 when Lugard resigned as High Commissioner of Northern Protectorate, the restrictions placed on Christian mission activities in the North tightened. Iwuchukwu has explored the relationship between Christian missions and colonial authorities. Emmanuel M. Abar has argued that this relationship of power politics was not only between representatives of the Christian mission and colonial authorities but also incorporated other parties: members of the Islamic religion and practitioners of traditional religions (Abar, 2019). Iwuchukwu demonstrates that during the administrations of Percy Girouard and Sir Hasketh Bell, Lugard's successors, "restrictions of Christian mission activities was (sic) even more severe and the application of the Indirect Rule system arrogated more powers to the emirs and less interference by the colonial administrators" (2013:25).

Iwuchukwu further notes that in these periods, "Christians were not only restricted from Muslim areas but also denied access to the non-Muslim minority ethnicities" (2013:25). The restrictions were severe, to the extent that Bell's assistant, Charles L. Towers, was well known for considering Christian missionaries as the "greatest menace" in the scheme of the British administration in the north. At the same time, the chiefs of Kabwir (Kano) and Sura were deposed for their active interest in Christianity (Iwuchukwu 2013:26).

With such restrictions, Christian missionaries did not remain silent. They began petitioning the local colonial authorities. In a 1911 letter written by the s.I.M., a resident officer was accused of tearing down churches, being motivated to promote Islam: "It has come to the knowledge of your Memorialists that some of the Resident Administrators in Northern Nigeria are of the opinion that it is the purpose and policy of your Government to allow free course to the propagation of the Mohammedan religion amongst Pagan tribes, while ... Missionaries of the Cross should be permitted to work only under a special privilege and license" (National Archives of Kaduna, (N.A.K.) SNP 7, 3754/1911, cited in Barnes 1995:428).

H.J. Read, from the office of the Under Secretary of the State for Colonies, responded and requested missionaries disentangle themselves from local affairs: "There will be a tendency among converts to pay more attention to the 
advice of the white missionary than to the orders of their own Ruler, and it is to be hoped that those who are engaged in mission work detach themselves, as much as possible, from interference in local secular affairs" (cited in Barnes 1995:429 - N.A.K. SNP 7, 3754/1911).

The missionaries changed their tactics, accusing the colonial government of obstructing religious liberty. This seemed to have rattled the authorities' resolve. They rallied together and responded that "the restrictions then in effect on Christian proselytizing in the North were 'not contrary to the principles of religious toleration'" (cited in Barnes 1995:429). Yet, the colonial authorities were afraid that missionaries would use their race as a battering ram to subdue and break down the emirs' authority. Hence, according to E.J. Arnett, an officer in Sokoto, to let Christian missionaries work among Muslims was not a question of toleration, "but of teaching Christianity at the point of a bayonet" (Arewa House Archives (A.H.A.), Kaduna, 15246, cited in Barnes 1995:429). This was necessary, since some colonial administrators thought the Protestant missionaries' main aim was an increase of converts. In addition, there were black missionaries like W.A. Thompson, a Caribbean C.M.s. worker, who taught that all men are equal (Barnes 1995:421, 422). ${ }^{1}$ Such ideas annoyed colonial authorities. Thus, colonial officers not only disliked white missionaries for their efforts, but they also totally disdained those black missionaries who undermined their authority and racial ideologies.

Furthermore, around 1917, the various Protestant missions in the North banded together to exert pressure on the colonial government. This time, the missionaries "changed their line of attack from accusing administrators of favoritism toward Islam to insisting that in Northern Nigeria the Colonial Office follow the same principle of religious toleration [as] in the rest of the empire" (Barnes 1995:414). Although Sir Hugh Clifford, who by 1924 was the Governor of Nigeria, insisted that the entry of Christian missions into the Muslim territories might arouse religious fanaticism, the argument of religious tolerance sounded very reasonable to Sir Graeme Thomson, appointed Governor in 1927. One of his first acts was a promise to relax the restrictions. He also gave a mandate to colonial administrators to help missionaries "identify possible sites in Muslim territories for mission stations" (Barnes 1995:414).

However, Thomson's mandate was resisted to some extent by his subordinates. For instance, in 1928, the C.M.s. was expelled from Zaria City, a decision highly influenced by H.R. Palmer, the Lieutenant-Governor and an advocate for exclusion of Christians from the North (Ubah 1987:17-18). In addition,

1 W.A. Thompson spent over thirty years in Nigeria where he worked on the translation of the Bible and the Prayer Book into the Nupe and Hausa languages. (See Newmann 1997:21). 
H. Herman-Hodge, the Resident in Ilorin, even argued that the government had granted "too much latitude" to the missionaries and "placed much reliance in their good faith" (cited in Barnes 1995: 431). Therefore, in the face of this resistance it is not surprising that at the Miango Conference (near Jos) in 1929, the mission societies interested in carrying out their activities in the North "expressed utter disgust with the policy of excluding the missionaries" from Muslim regions (Ubah 1987:17). As a result, it was agreed the matter would be discussed in a meeting at London with the governor of Nigeria (Ubah 1987:17).

Consequently, in London, 1930, Dr. Oldham, Secretary of International Missionary Council or International Council of Missions, arranged a meeting of the heads of Missions, government officials, and the Governor of Nigeria. A consensus was reached since the Governor seemingly allowed mission access to the emirates of Northern Nigeria. Nonetheless, the colonial government was not interested in applying "pressure on the emirs with a view to making them allow the missionaries into their territories" (Ubah 1987:17). On the other hand, Ubah relates, the authorities promised not to do anything "which might give the emirs the impression that it expected them to reject requests for missionary enterprise. The government was interested in educating the emirs on the principles of religious toleration but would do so gradually ..." (1987:17).

At this point, although there was no clarity in the relaxation of the restrictions, the 193os began with renewed hope for missionizing the Muslim North. Palmer, who had been serving as Lieutenant-Governor, was replaced in 1930 by C.W. Alexander, who "was not committed to the preservation of the status quo in the North" (Ubah 1987:18). Thus, a letter from the new Lieutenant-Governor's office requested the colonial resident officers give a complete report on the missionary progress in the Muslim areas of the province (A.H.A. 5533, vol. I, 188, as quoted in Barnes 1995:430). In the administrators' replies, the spirit of resistance still colored the reports, which either undermined the missionaries' deficiencies or lack of success. Yet, the fact that there were some positive notes showed that things were changing for the better (Barnes 1995:432-433).

In 1931, when Sir Donald Cameron replaced Thomson as governor of Nigeria, the "coming of a new governor may have suggested to the missionaries that this was a good opportunity to try again before he fell into the hands of the antimissionary groups" (Ubah 1987:18). That year, during his first visit to Kaduna the headquarters of the Northern Provinces administration - Cameron held an important conference with representatives of the S.I.M., the S.U.M., and the C.M.s. At the meeting, H.G. Farrant (s.U.M.) "made the point that it was four years since Sir Graeme Thomson promised a change of policy, and the missions wished to know what the chances were of their being allowed to acquire sites for the purpose of missionary and other activities" (Ubah 1987:18). 
Cameron's response may be summarized as follows: missionary efforts could proceed cautiously and with the right personnel; there was to be no interference with administration; missions were to operate within distinct spheres of influence (which was not a new idea); and a prohibition on public preaching in the emirates was readily accepted by the missionaries (Ubah 1987:18-19).

With the official policy, those areas and regions earlier dominated by mission societies were agreed upon as their spheres of influence. The Roman Catholic Mission (R.C.M.) and the C.M.s. had carved out their spheres around Lokoja and Nupe land and parts of Benue Province, including Shendam, which initially was administered as part of Muri Province. The S.I.M. and S.U.M. dominated most parts of Niger Province, southern Zaria and Plateau Provinces, including Kaltungo in Gombe and Mubi in southern Borno Province, while the Lutheran Church had its headquarters at Numan in Adamawa Province (Crampton 1976; Kalu 1978).

Therefore, as the policy of restriction was being relaxed, there was a developing relationship between the colonial administration and some Christian missions. At the same time, the Christian missions in the North seemed to have settled internal squabbles and became more organized, with a united goal of missionizing the North. Barnes concludes that it was as a result of their previous struggle with the administrators that they were able to fully work a division of territories based on the concept of "spheres of influence" (Barnes 1995:436). During that time, the Adventists came on board, oblivious to the zeitgeist that ruled the colonial Muslim North.

Adventist Missionaries and Other Christian Missions in Nigeria: Mission Rivalry

When the S.D.A. appeared on the scene after three decades of the imposition of colonial rule in the North, almost all the available spheres of influence had been allocated to the earlier missionaries. The spheres of influence became the source of rivalry between Adventists and the s.I.M., explored below.

\subsection{A Reconnoitering Visit}

With the aim of carrying out mission activities across the northern banks of the rivers Niger and Benue, three s.D.A. leaders visited Jos to explore the possibility of entering Plateau Province. The team consisted of McClements, Superintendent of the Adventist Mission in Nigeria, W.E. Read, President of the West African Mission fields, and John J. Hyde, Director of Northeast Mission. On arrival, they were granted audience with the Resident of Plateau 
Province on February 9, 1931. During the interview, the purpose of the visit was succinctly spelled out: "they wished to open a Medical Mission in the Plateau Province." In response, the Resident "gave a brief resume of the position of Missions in the Plateau Province ... [and] suggested that the [s.D.A.] Mission should get in touch with the Council of Missions and put up concrete proposals, when the matter could be further considered" (Clarke and Monsell 1931; N.A.K. Jos Prof 120/1931).

It is likely that the "Council of Missions" was the International Council of Missions or International Missionary Council which was constituted in 1921 and integrated into the World Council of Churches in 1961. The Council was in England, where its secretary, Dr. Oldham, had organized the stakeholders' meeting of 1930 regarding mission access to the emirates. Thus, the Council had become an important player in advising the colonial office in this matter. Until this time, Adventists were either very hesitant to ecumenical endeavors or maintained a very low involvement with other mission bodies. ("Our Relationship to Other Societies (1919)" 1920; Höschele 2016). Thus they had little or no dealings with the Council. Hence, they did not consult other Christian missionaries on this matter and were not informed of the politics in place. In any case, the team was asked to formally request a sphere of influence for its operation, which was possible after consulting with the Council.

Without reference to the Council of Missions, Hyde submitted a formal application for the establishment of an S.D.A. mission station in Plateau Province. On February 12, 1931 a telegram was sent from Kaduna to the Resident of Plateau Province, who in turn directed it to the Officer in charge of Pankshin Division: "[s.D.A.] Mission whose work at present [is] confined to the Southern Provinces [is] anxious to open a Station in Northern Provinces. Essential site should be in or near country [with] high altitude but not clashing with sphere of any other Mission. [The] Station will combine (a) Leper Work (b) Native Hospital (c) Health Station for European Missionaries. Indicate by telegram what localities you suggest as suitable. Proposal is for single Station and not wide sphere of influence" (N.A.K. Zar Prof. 41, 1932).

Although there was no consultation with other missionaries, during the interview with the Resident of Plateau Province, Hyde must have gotten an inclination that the colonial administrators preferred mission activities that helped to alleviate social and economic problems, which may explain their starting with medical missions in the North. As Shobana Shankar observes, the colonial administrators were fearful of "propaganda." Hence, they "recommended that medical missions first be let into 'pagan' areas of Northern Nigeria, where they could prove their trustworthiness to native and 
British authorities and then later be rewarded with sites in Muslim areas" (Shankar 2014:329).

Doing medical missions on the peripheries of Muslim-dominated regions was in line with Cameron's policy of establishing work in the fringes which gave allowance to be invited by the emirs. It was also in line with Lugard's program of social reform, which he hoped Christians would carry out (Barnes 1995:436).

After due consideration of the Adventist application, on February 23, 1931, the Resident of Plateau Province conveyed the response of the Divisional Officer in charge of Pankshin: "there is no area on the high ground of Pankshin suitable for the establishment of a new Mission, as the [s.U.M.] is already operating in the Gindiri, Sura, and Hill Angas Districts and has sent evangelists to the Kaleri and Ron Districts" (Monsell 1931; N.A.K. Zar Prof. 41, 1932).

On the advice of the Plateau Resident, two alternative locations were given. The first was near Rumfan Gwamna, some twelve miles north of Jos along the main Jos-Zaria road. This site was judged suitable and healthy for the establishment of a mission station. The other option was in the neighborhood of Kachia or Zangon Kataf in southern Zaria. Of the two places, only Rumfan Gwamna seemed to have been free for the Adventists to establish their station without any conflict with another mission. Despite the apparent advantages, the Adventists were less enthusiastic about the prospect of establishing a station there, due to the relatively sparse population, while the second site at Zangon Kataf was much more attractive. When the second alternative was conveyed to McClements, he wrote, "I shall be pleased to convey this information to our Board in London on my returning to England early in April. In the meantime one of our representatives will investigate the location to which you have referred and undoubtedly call and see you."2

In response, Hyde undertook a visit to see the Resident of Zaria and expressed his desire to proceed to Zangon Kataf, which he considered more suitable for mission. Accordingly, when Hyde inspected the site on April 20, 1931, he submitted an application for a Certificate of Occupancy. In the covering letter to the D.o. he stated:

We are generally known as the 'Seventh-Day Adventist Mission.' Our property in Nigeria is held under a Power of Attorney granted by the General Conference Corporation of Seventh-Day Adventists, of

2 N.A.K., "Minutes" in the Memorandum No 14432/11, from Secretary Northern Provinces, Kaduna, To Resident, Zaria Province, "1 March 1931, on Seventh-Day Adventist Mission Establishment of." 
Washington D.C. ... Our building lease is required for purposes of erecting the following buildings: European Residence; Houses for Native Assistance; Mission Dispensary; School for Pagan Children; and a Hospital ... It is our purpose to commence the Medical side of our work in a Dispensary, and to grow on into a Hospital as the work increases. Hence our request for 15 acres of land and for 5 years in which to complete the buildings ... It is possible that experience may indicate a more suitable site for the permanent Hospital ... All this, however is only a possibility ... Trusting that you will find everything in order, and that nothing will arise to cause undue delay in the completion of this matter.

HYDE 1931: N.A.K. Zar. Prof. C.4O2 vol. II ${ }^{3}$

Unfortunately, many problems encumbered the processing and granting of the application. On receiving it, the D.o. of Zaria forwarded it to the Resident, explaining that the matter had been discussed with the Assistant D.o. Mr. Roberts, who thought that there was no objection (N.A.K. Zar. Prof. C.4O2 vol. II ). ${ }^{4}$ Indeed, Roberts discharged his work very well when he was instructed to visit the site of the application to make sure that there would be no problems with the local population. In his report, Roberts stated: "I have inspected this site with Katuka. At the moment it is a farmland, but no hardship will occur to the local natives if it is handed over" (Roberts 1931: N.A.K. Zar Prof 41, 1932). Roberts also indicated that Katuka agreed with the plans of building a hospital and the mission's focus among non-Muslims.

But the accompanying District Officer's note also called the Resident's attention to another application from the S.I.M. requesting permission to work in the same sphere of influence, though no action had been taken. It was this clash of interest for Zangon Kataf that brought the s.D.A. and S.I.M. into an unhealthy rivalry.

\subsection{Missionary Rivalry}

Though the idea of creating spheres of influence was to prevent unhealthy rivalry and to minimize open confrontation between missionaries, the story on the ground was very different. It is a fact that wherever and whenever spheres

3 J.J. Hyde, Seventh-Day Adventist Mission Nigerian Branch, P.o. Box 19, Ibadan, a letter addressed to: District Officer i/c Emirate Division, Zaria, April 2oth 1931, N.A.K. Zar. Prof. C.4O2 vol. II.

4 A similar positive response was given by the emir of Zazzau, who expressed his willingness to allow it so long as the Mission only worked among the "pagan" population. Immediately after the application was received, a request to visit the Katabawa was made by the "s.I.M. of Kagoro" (Daniel 1929-1932:65). 
of influence were created, either for the conduct of commerce and trade, or for missionary enterprise, intense competition and clashes were inevitable. In the northern region of the rivers Niger and Benue, there was a wide expanse of space among the non-Muslim societies for the early arrivals. Thus, there were no problems and no accounts of unhealthy rivalries among the missionaries. Over time, however, with an increase in the number of denominations and the expansion of their activities, available spheres of influence diminished significantly. This was the situation by 1931 when Adventists wished to missionize in Zango Kataf. Since the response of the Resident in Zaria was not positive, McClements' reply to the District Officer in charge of Zaria Division indicates the intractable nature of the problem:

Your letter ... dated 19th ... came to me a few days ago, and I must admit being somewhat surprised at its contents; however, I appreciate your thought in the matter of referring our application back to us before proceeding further with it.

2. We understood that the S.I.M. had a station at Kagoro in the Plateau Province, but we also understood that their work had not as yet extended to the Katab people.

3. As you know, we have been deeply impressed with the situation at Zangon Katab and the large tribe of Pagan people there amongst whom little or nothing has been done along Missionary lines thus far. It seems to us that in working for these people and building up a medical work there we could have a good location, and would not be so likely to clash with other Missions as we might elsewhere.

4. We would therefore be glad if you would proceed with our application for the site at Zangon Kataf, as it seems to be the best opening we have seen so far.

5. I am sending a copy of your letter by this mail to our Mission Board, and also to Mr. Hyde who is in England at present, with the request that they cable me if they advise us to withdraw the application, in which case I would immediately communicate with you.

MCCLEMENTS 1931: N.A.K. Zar Prof 41, 1932

On the receipt of this letter, the officials in Zaria responded: "Resident/I suggest that we defer action on this application for a $\mathrm{C}$. of O. until we receive the communication promised ... and until we know more about the intention of the S.I.M. with regard to Zangon Kataf" (N.A.K. Zar Prof 41, 1932). From the Provincial Office, the Resident of Zaria communicated the decision of s.I.M to McClements. 
... I have the honour to inform you that I have received a letter from the [s.I.M.] in reply to a letter from me informing them that you had applied, on behalf of your mission, for a site at Zongon Katab.

2. After expressing regret that your Mission has made the application they put the following points: -

(a). The Katab people speak the same language as the Kagoros (amongst whom they are at present working in Plateau Province) and intermarry. The Katab extend to within eight miles of Kagoro and are different only in name.

(b). Zongon Katab lies between their stations at Kurmin Musa and Dama Kasuwa while Kagoro is only a few miles to the south.

(c). That they made application for a site at Zongon Katab three years ago, but that before definite action was taken those who were to have opened the station were invalided and the project was dropped for the time. That they have never abandoned the idea of eventually working among the Katab tribe and that it is a natural field for their evangelists.

(d). That confusion will arise if two missions work in such close proximity among a tribe with a limited population.

3. In view of the above I shall be glad to know if you will reconsider your proposal to open a Mission Centre at Zongon Katab.

MCCLEMENTS 1931: N.A.K. Zar Prof 41, 1932

By this time, reorganization had taken place within the Adventist Mission. They changed their name to Nigerian Union Mission of Seventh-Day Adventists. McClements responded indicating his displeasure over the situation. He seemed to be irritated over the fact that Adventists were not consulted on the issue of spheres of influence:

I am in receipt of your letter..., and note what you state regarding the attitude of the Sudan Interior Mission to our opening up work at Zangon Katab. We, too, regret very much that the S.I.M. should take up this attitude towards our proposed work in that district. As expressed in my previous letter [...] we feel very much drawn to the Zangon Katab. The Mission Board at home has been deeply impressed by the report we sent on our return from Zaria in April and they are anxious for us to locate there and build up a Medical Mission centre.

In view of the fact that our interests were not consulted when spheres of influence were allocated by the S.I.M and other Missions - though we have been operating within the Northern Provinces for the past sixteen 
years - it is probable we should have encountered similar opposition had we decided upon the other districts suggested.

We certainly desire to work as much as possible in harmony with other Missions, but, after giving careful consideration to all the points raised, we would still feel very reluctant to withdraw our application [...].

MCCLEMENTS 1931: N.A.K. Zar Prof 41, $193^{2}$

Having analyzed the two positions by S.D.A. and S.I.M., the Resident of Zaria wrote to the Secretary of Northern Provinces, lamenting in the end that, "in the circumstances there would appear to be no alternative but inform the Seventh-Day Adventists that their application cannot be granted" (1931: N.A.K. Zar Prof 41, 1932).

By this time, Hyde had already established himself at Zangon Kataf in the hope of building permanent headquarters on this site for the Adventist Mission work in Northern Nigeria. In a progress report on the Nigerian front, McClements enthusiastically wrote to the Adventist public citing God's providence in doing medical mission in Zagon Katab: "The people of this area ... are anxious for us to open a dispensary or hospital here, and have given us a large tract of land for this purpose. The English officials also welcome us into the district with our medical work. So we believe the Lord has been directing us to this section of the northern provinces in a special manner" (McClements 1931:9).

Unaware of the Adventist enthusiasm, the Secretary of Northern Provinces conveyed the decision of the Lieutenant Governor to the Resident of Zaria, saying, "... it is desirable that Missionary bodies should agree among themselves to avoid interference in their respective spheres of influence ... I am to say that you should represent this point to the Seventh-Day Adventist Mission who in the circumstances might be prepared to reconsider their application, and that you understand there would be no objection" (Thompstone 1931: N.A.K. Zar Prof 41, 1932).

In a further communication on this matter, the Resident of Zaria informed McClements that the authorities did not approve the Adventist application for Zangon Kataf. At the same time, the Resident of Plateau was also contacted to confirm about Rumfan Gwamna. However, there was no need for confirmation because McClements and Hyde had earlier seen the Resident, Mr. C.A.N. Clarke on the issue. Since the S.I.M. claimed the area of Zangon Kataf as one of their spheres of influence, the Adventists were advised to withdraw their application. In Clarke's view, the application was withdrawn immediately (Clarke 1931: N.A.K. Zar Prof 41, 1932). 
However, the problem persisted. On September 7, 1931, McClements wrote to the Resident of Zaria, inquiring about their application for Zagon Kataf (McClements 1931: N.A.K. Zar Prof 41, 1932).

In his reply, the Resident asked McClements to reconsider the problem of the site in view of the strong points previously raised by Mr. Playfair of the s.I.M. Since he was not prepared to accept defeat, McClements visited the Resident in Zaria on November 10. However, he was advised to settle the matter with the S.I.M. The prospects for other sites at Kauru, Birnin Gwari, and Kachia were also discussed, none of which were acceptable to McClements.

Undeniably, it was an intense rivalry between the S.D.A. and S.I.M. over the spheres of influence, particularly in the southern part of Zaria Province. Seeing no headway, McClements decided to go in person to discuss the matter with the director of s.I.M. in Jos and promised to communicate the outcome with the Resident of Zaria. Despite the intensity of the rivalry, the two bodies finally resolved the issue and settled their problem by demarcating boundaries for their respective spheres of operations. After the meeting, on November 20, McClements wrote,

This is to inform you that we have had several friendly discussions with the Director of the S.I.M. and have agreed to withdraw our application for site at Zangon Kataf in their favor. Mr. Playfair ... has assured us that the S.I.M. have no intention of pushing further into the Zaria Province unless we fail to occupy it.

I understand Mr. Playfair is writing you immediately to confirm this. We are planning to make a further survey of the southern part of the Province with a view to making a new application [...] We expect to call and see you in about ten days' time.

PLAYFAIR 1931: N.A.K. Zar Prof 41, $193^{2}$

As expected, Playfair, in confirming the above, reported that the Adventists had withdrawn their application for Zagon Katab. He also stated that the s.I.M. had no intention of pushing further into Zaria Province as McClements had stated (1931: N.A.K. Zar Prof 41, 1932).

McClements returned to Ibadan and reported the matter to the Board, where his withdrawal of the application was discussed and ratified. He then wrote to the Resident of Zaria affirming the final decision of the Mission on the matter: "I am writing with reference to our former application for a site in Zaria Province and wish to state that we have decided, after careful consideration and consultation ... to open our work in Jos Division. We will 
therefore, for the moment, withdraw our application for Zangon-Kataf and await another suitable opening where we can utilize the experience gained in Jos" (McClements 1932: N.A.K. Zar Prof 41, 1932). With the bitter rivalries behind them, the s.D.A. Mission then embraced the task of choosing a suitable alternative site upon which to develop a permanent center for its operation in Northern Nigeria.

\subsection{Establishing a Permanent Mission Station}

The long-drawn-out contest over the sphere of influence with the S.I.M. caused unnecessary delays in the establishment of a permanent base of operations for the Adventist mission. The discussions took almost a year before the mission could turn its attention to Jengre, in Jere District of Jos Division, without fear of clashes. The presence of the Adventist station in this area confined the activities of S.I.M. around Zabolo some twenty miles away from Jengre. Hyde and his wife, a trained nurse, relocated to Jengre around December 31, 1932. They brought along a Hausa man who had been recruited to assist with dispensary work while at Zangon Kataf. Led by Mrs. Hyde, the dispensary, which later became the Jengre S.D.A. Hospital, provided an avenue to reach the people in the area who were in dire need of medical treatment.

There was an epidemic of jigger during the first year of the stations' establishment, and the effectiveness of the treatment given to those who attended the mission station drew quite a large number of people. From December 1931 to March 1932, a temporary booth of woven grass (zana) was built where sick people received treatment, and where Bible lessons and Sabbath worship were initially conducted (L.M. Hyde 1994).

Having firmly established the mission work at Jengre, Hyde was then prepared to launch Adventism in and around the villages of the area. Among the first people who demonstrated keen interest in the Adventist mission work were Mallam Lamba Kakwi and Kaji Dariya. These two had previously been in contact with S.I.M. missionaries operating from Jos. With the establishment of the Adventist station very close to them, they were more than happy to embrace the new Sabbath teachings.

Hyde depended initially on Kakwi and Dariya for the expansion of the s.D.A. mission to the surrounding villages (Maigadi 2005:38-44). He understood the need to have a knowledge of the Hausa and Amo languages and labored to build relationships in his community. Notable was the relationship he had with the Kakwi family. The four sons of Kakwi - Lamba, Mayang, Filibus, and Simon - became his "disciples" and worked as pioneers in their community. They all later became Adventist ministers. Before Hyde left for Sierra Leone in 
1942, a semi-formal school where adult education was emphasized had begun. Hyde was replaced by L.W. Normington, who ushered in a second phase of Adventist mission in the North of Nigeria.

\section{5}

\section{Conclusion}

This article has argued that the reason for the apparent difficulties faced by early S.D.A. missionaries in the North of Nigeria can be hinged on three factors. Their relative lateness to the missionary scene in Nigeria, combined with the colonial policy that restricted Christian mission activities in the North, delayed the Adventist mission. By the time the restrictions were relaxed, other Christian missionaries had developed cordial relationships with the colonial authorities, agreeing on a number of policies, chief of which was the spheres of influence for mission activities.

By the time Adventist missionaries arrived, other Christian missions were firmly established in Nigeria. Unaware and reluctant to consult other missionaries, S.D.A. missionaries were pushed into an unhealthy rivalry with the S.I.M. in a bid to establish a permanent mission station. This caused an unnecessary delay that could have been avoided had Adventists arrived earlier. Moreover, if Adventists had been willing to consult other mission bodies initially, they would have learned about the colonial politics that ruled the missionary scene of Northern Nigeria.

While this article has given insight into mission rivalry, which was not uncommon in the Nigerian mission field (Ekechi 1972 and Bassey 1991), its focus was on the history of the beginnings of the S.D.A. as an unlikely mission group which does not appear frequently in scholarly works on mission historiography in Nigeria. This is a lacuna that remains unmapped in the story of Christian mission in Nigeria. Moreover, the medical and educational contributions of the Adventists in the North of Nigeria under the auspices of Christian mission remains underexplored. This is an element that can ultimately contribute to a more robust picture of mission historiography in Nigeria.

\section{Acknowledgments}

In 2019, Chigemezi Nnadozie Wogu met with the late Prof. John Garah Nengel while doing ethnographic and historical research in the North of Nigeria. Prof. 
Nengel gave him the full rights to revise and co-author a manuscript titled "Conspectus History of Adventist Mission in Northern Nigeria, 1931-1948." While the manuscript was being reworked, unfortunately, Prof. Nengel died on May 7, 202O, before Ch.N. Wogu had finished additional research he produced for it. This article is a substantially revised essay of J.G. Nengel's former manuscript and therefore published as co-authored. It is dedicated to Prof. Nengel's memory and academic contributions.

\section{Abbreviations}

A.H.A. Arewa House Archives, Kaduna

C.M.s. Church Missionary Society

N.A.K./Jos Prof./ National Archives of Kaduna/Jos Provincial File/Zaria

Zar Prof. Provincial File

S.D.A. Seventh-Day Adventist

S.I.M. Sudan Inland Mission

S.U.M. Sudan United Mission

\section{References Cited}

Abar, Emmanuel M. (2019). Islam, Christianity, Traditional Religions and Power Politics in Northern Nigeria Since Pre-Islamic Period. PhD diss., Andrews University, Berrien Springs, MI.

Ajayi, J.F. Ade. (1965). Christian Missions in Nigeria 1841-1891: The Making of a New Elite. London: Longman Group Ltd.

Arewa House Archives, Kaduna (1930, 1931, 1932). Files and letters related to Christian Missions/Establishment of Seventh-Day Adventist Mission.

Barnes, Andrew E. (1995). “Evangelization Where it is Not Wanted': Colonial Administrators and Missionaries in Northern Nigeria During the First Third of the Twentieth Century." Journal of Religion in Africa 25 (4):412-441.

Baur, John (1994). 2000 Years of Christianity in Africa: An African Church History. Nairobi: Paulines Publications Africa.

Burgess, Richard (2008). Nigeria's Christian Revolution: The Civil War Revival and Its Pentecostal Progeny (1967-2006). Oxford: Regnum Books International.

Christian, L.H. (1931). “The Annual Division Meeting." The Advent Survey 3 (1):1-2. Crampton, E.P.T. (1976). Christianity in Northern Nigeria. Zaria: Gaskiya Corporation. 
Danmole, H.O. (1990). "Religion and Politics in Colonial Northern Nigeria: The Case of Ilorin Emirate." Journal of Religious History 16 (2):140-153.

Dick, E.D. (1933). "The West Coast of Africa - No. 2." The Advent Review and Sabbath Herald 9o (33):9-10.

Egharevba, Jacob (1968). A History of Benin. Ibadan: Ibadan University Press.

Falola, Toyin and Heaton, Matthew M. (2008). A History of Nigeria. Cambridge: Cambridge University Press.

Faught, C. Brad (2001). "Missionaries, Indirect Rule, and the Changing Mandate of Mission in Colonial Northern Nigeria: The Case of Canada's Rowland Victor Bingham and the Sudan Interior Mission." Journal of the Canadian Church Historical Society 43:147-169.

Galadima, Bulus Y. and Turaki, Yusufu (2001). "Christianity in Nigeria: Part I." African Journal of Evangelical Theology 20 (1): 85-101.

General Conference of Seventh-day Adventists (1932). "Nigerian Union Mission." Seventh-day Adventist Yearbook. Washington, D.C.: Review and Herald.

Hastings, Adrian (1994). The Church in Africa, 1450-1950. Oxford: Clarendon Press, 1994. Höschele, Stefan (2016). "Interchurch Relations in Seventh-Day Adventist History: A Study in Ecumenics." Habilitation Thesis, Evangelical Theological Faculty, Charles University, Prague.

Hyde, L.M. (1994). Fieldwork: Watford, England.

Isichei, Elizabeth (1995). A History of Christianity in Africa: From Antiquity to the Present. London: SPCK.

Ising, Walter K. (1928). "Visiting West Africa." Quarterly Review of the European Division of Seventh-day Adventists 14 (1):2-4.

Iwuchukwu, Marinus C. (2013). Muslim-Christian Dialogue in Post-Colonial Northern Nigeria: The Challenges of Inclusive Cultural and Religious Pluralism. New York: Palgrave Macmillan.

Lashier, S.J. (1924). "From West Africa." North Pacific Union Gleaner 19 (29):2-3.

Lugard, Frederick. D. (1965). The Dual Mandate in British Tropical Africa. London: Frank Cass \& Co.

Maigadi, Ibrahim. B. (2005). The Adventist Church in Northern Nigeria: A Historical Source Material of Seventh-day Adventist Church in Nigeria. Zaria: Culture Impressive.

McClements, William (1930). "Nigerian Union Mission." The Advent Survey II, 11:2.

McClements, William (1931). "Progress in the Nigerian Mission Field." The Advent Review and Sabbath Herald 108 (34):9.

National Archives of Kaduna (1930, 1931, 1932). Files and letters related to Christian Missions/Establishment of Seventh-day Adventist Mission.

Nengel, John G. (N.D.) "A Conspectus History of Adventist Mission in Northern Nigeria, 1931-1948." Unpublished Manuscript. 
Newmann, Las G. (1997). “The Caribbean's Response to The Great Commission: History and Models of Response." Caribbean Journal of Evangelical Theology I, 1:16-32.

"Our Relationship to Other Societies (1919)" (1920). Advent Review and Sabbath Herald $97(34): 5^{-6 .}$

Perham, Margery (1960). Lugard: The Years of Authority, 1898-1945. London: Collins.

Read, W.E. (1930). "The Message in Nigeria." The Advent Review and Sabbath Herald 107 (43):14-15.

Read, W.E. (1931). "Progress in West Africa." The Advent Review and Sabbath Herald $108(26): 16-17$.

Shankar, Shobana (2014). Who Shall Enter Paradise?: Christian Origins in Muslim Northern Nigeria, Ca.189o-1975. Ohio: Ohio University Press.

Ubah, C.N. (1987). "Christian Missionary Penetration of the Nigerian Emirates, with Special Reference to the Medical Missions Approach." The Muslim World 57 (1):16-27.

Watson, Noelle (1996). "Benin City Nigeria." International Dictionary of Historical Places: Middle East and Africa. Chicago, Illinois: Fitzroy Dearborn:125-128.

Wogu, Chigemezi N. (2019). "Trailblazers of Adventism in Nigeria, 19oos-193os." Journal of Adventist Mission Studies 15 (2):1-13.

\section{摘要}

与在尼日利亚南部和西部取得的相对成功来比, 从 1930 年代起, 基督复临安息日 (S.D.A.) 在建立其北方的宣教机构遇到了些困难。本文认为, S.D.A. 宣教士发现北 方宣教困难的原因有三个。首先, S.D.A. 在尼日利亚加入基督教宣教士的舞台相当 晚。其次, 由于殖民政治不利于北方基督教宣教士的传教目的, 基督复临会宣教 士发现并不容易立即建立宣教机构。第三, 尼日利亚北部的艰难开端也可归因于 S.D.A. 宣教士与其他宣教机构之间的关系, 由于殖民政府建立的 “势力范围” , 这 些宣教机构趋向于竞争。

\section{Resumen}

A partir de 1930 la Iglesia Adventista del Séptimo Día (s.D.A. por sus siglas en inglés) tuvo ciertas dificultades para establecer su misión en el norte de Nigeria si se compara con el éxito relativo en la zona meridional y occidental de ese país. Este artículo argumenta que hubo tres razones por las que los misioneros de la S.D.A. encontraron dificultosa la zona norte. En primer lugar, la S.D.A. ingresó más bien tarde al ámbito misionero cristiano en Nigeria. En segundo lugar, debido a las políticas coloniales, que 
no contribuyeron a las metas proselitistas de los misioneros cristianos en el norte, a los misioneros adventistas les resultó difícil establecer una misión de manera inmediata. En tercer lugar, los comienzos difíciles en el norte de Nigeria también se pueden atribuir a la relación entre los misioneros de la s.D.A. con otros grupos misioneros, que tendía a la rivalidad, como resultado de las "áreas de influencia" establecidas por el gobierno colonial. 